DIGITAL COMMONS
@ UNIVERSITY OF SOUTH FLORIDA

Volume 5

Issue 1 Volume 5.1 (Spring 2015)

\section{ABO: Interactive Journal for Women in the Arts, 1640-1830}

2015

\title{
Reporting on What Jane Saw 2.0: Female Celebrity and Sensationalism in Boydell's Shakespeare Gallery
}

Janine Barchas

The University of Texas at Austin, barchas@austin.utexas.edu

Follow this and additional works at: https://digitalcommons.usf.edu/abo

Part of the Ancient, Medieval, Renaissance and Baroque Art and Architecture Commons, Digital Humanities Commons, and the Feminist, Gender, and Sexuality Studies Commons

\section{Recommended Citation}

Barchas, Janine (2015) "Reporting on What Jane Saw 2.0: Female Celebrity and Sensationalism in Boydell's Shakespeare Gallery," ABO: Interactive Journal for Women in the Arts, 1640-1830: Vol.5: Iss.1, Article 1.

http://dx.doi.org/10.5038/2157-7129.5.1.2

Available at: https://digitalcommons.usf.edu/abo/vol5/iss1/1

This Digital Humanities is brought to you for free and open access by Digital Commons @ University of South Florida. It has been accepted for inclusion in ABO: Interactive Journal for Women in the Arts, $1640-1830$ by an authorized administrator of Digital Commons @ University of South Florida. For more information, please contact digitalcommons@usf.edu. 


\title{
Reporting on What Jane Saw 2.0: Female Celebrity and Sensationalism in Boydell's Shakespeare Gallery
}

\author{
Abstract \\ This essay reports on ongoing efforts to build an accurate digital model of John Boydell's popular \\ Shakespeare Gallery precisely as it looked in August 1796-when a 20-year-old Jane Austen visited \\ London's sites, staying within a ten-minute walk from the gallery. The essay argues for the substantial \\ difference between studying Boydell's pictures in a paper volume (whether as lists, illustrations in books, \\ or engraved folio plates) and viewing them as an exhibition of paintings on walls, albeit virtual ones. For \\ example, the digital reconstruction illuminated commissions from several female participants in Boydell's \\ male-dominated gallery, especially Angelica Kauffman (1741-1807) and Anne Seymour Damer \\ (1749-1828). In addition, the essay also recounts how the celebrity of model Emma Hart/Hamilton \\ (1765-1815) safeguarded one Boydell painting from oblivion while The Shakespeare Gallery proved the \\ site of a strange form of self-promotion practiced by actress Mary Wells (1762-1829). Our digital \\ visualization of an historic exhibition in 1796 brought the controversial celebrity of a few women artists \\ into focus. In sum, this essay shows DH methodology in action while sampling what might be gleaned \\ when digital tools serve historical scholarship in the humanities.

\section{Keywords} \\ digital humanities, digital heritage, museum recreation, Georgian spectacle, John Boydell, Shakespeare \\ Gallery, female artists, Angelica Kauffman (1741-1807), Anne Seymour Damer (1749-1828), Emma Hart/ \\ Hamilton (1765-1815), Mary Wells (1762-1829)

\section{Creative Commons License} \\ (c) $\odot \ominus$
}

This work is licensed under a Creative Commons Attribution-No Derivative Works 3.0 License. 
On 24 May 2013, What Jane Saw (www.whatjanesaw.org) launched a digital reconstruction of a museum exhibition that Jane Austen witnessed two centuries earlier. I am thrilled to be working with yet another team from Liberal Arts Instructional Technology Services at the University of Texas, Austin. This time, we are reconstructing John Boydell's temple to Bardolatry: the popular Shakespeare Gallery, which operated from 1789 to 1804 along Pall Mall in London. Paying a one-shilling entrance fee, thousands of Georgian visitors came to view the gallery's giant canvases (many with life-sized figures) of scenes from Shakespeare's plays. We are rebuilding Boydell's public spectacle as it looked in 1796 — when a twenty-year-old Jane Austen visited London's sites, staying within a ten-minute walk of the gallery. Targeted for completion around December 2015, our digital reconstruction will allow a modern viewer to see Boydell's paintings in situ for the first time since its closing in 1804. This means that the first public museum dedicated to William Shakespeare, a Georgian entertainment that scholars have written about as instrumental in making The Bard a national icon, can finally be revisited (albeit in virtual space) - and just in time for the many celebrations that will mark 400 years of Shakespeare's literary afterlife in 2016.

Alderman and print seller John Boydell (1720-1804) opened "The Shakspeare Gallery" (he preferred this archaic spelling) on 4 May 1789. The gallery was the first of an ambitious three-part entrepreneurial plan to define Britishness with contemporary art. The enterprising thespian David Garrick (1717-1779), supreme leader of the new Bardolatry, had made a career out of placing Shakespeare at the center of British identity. Boydell similarly wished to foster a nationalist celebration of Shakespeare that might endorse his preferred artistic forms, namely history painting and contemporary engraving. The gallery was one of three interlocking projects: the second and third concerned an ambitious new edition of Shakespeare's plays and a set of elephant folio engravings of the gallery's paintings. These engravings would be available for separate purchase as handsome prints as well as illustrate the new edition in a smaller format.

Over the gallery's fifteen-year history, Boydell commissioned works from leading, and not so leading, artists. Present in the upper gallery in 1796 are 84 paintings plus two stone works by the following heady mix of artists: Josiah Boydell, Mather Brown, Anne Seymour Damer, Joseph Farington, Henry Fuseli, John Graham, Gavin Hamilton, William Hamilton, John Hoppner, Angelica Kauffman, Thomas Kirk, William Miller, James Northcote, John Opie, Rev. Matthew W. Peters, John Henry Ramberg, Sir Joshua Reynolds, John Francis Rigaud, George Romney, Robert Smirke, Thomas Stothard, Henry Tresham, Benjamin West, Raphael West, Richard Westall, Francis Wheatley, and Joseph Wright. 
Challenges facing any digital recreation include: 1) the loss of many of the original paintings, whose compositions are recorded by Boydell's own engravings but whose canvas sizes often remain unknown, 2) the aggregate nature of the gallery during its fifteen-year span, which annually added and shifted paintings to freshen displays for visitors, and 3) the lack of a visual record of the gallery's original hang. The only picture of the interior is this small watercolor sketch by Francis Wheatley of royal guests at the annual reopening in 1790.

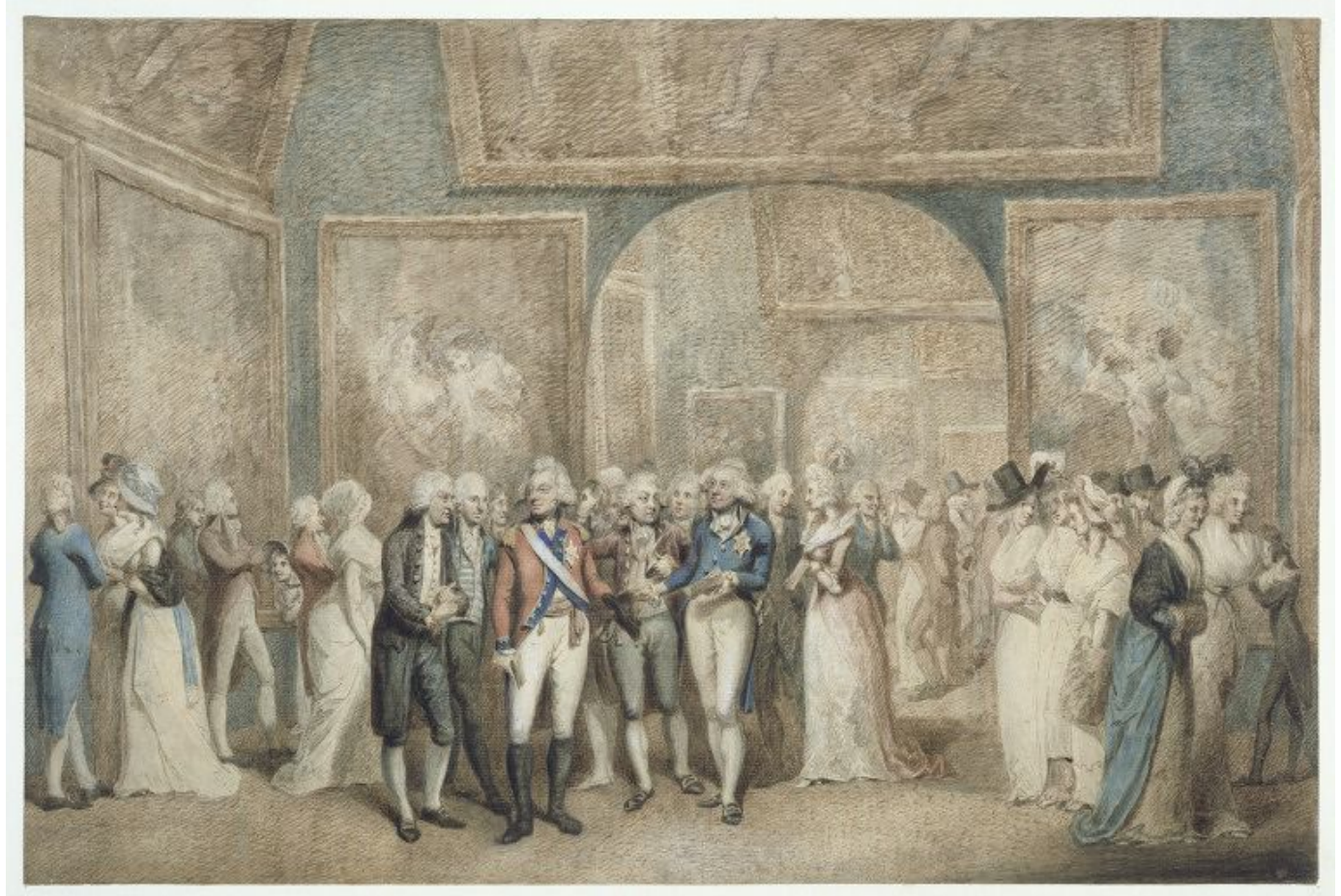

Figure 1: Francis Wheatley, "View of the Interior of the Shakespeare Gallery" (1790). Watercolor on paper. Victoria \& Albert Museum. URL: http://collections.vam.ac.uk/item/O77440/view-of-the-interior-of-watercolourwheatley-francis-ra/

Although this sketch provided a few starting clues (including wall color), with no comprehensive scholarly inventory, or catalogue raisonné, for the Shakespeare Gallery and only about 30 of the 84 paintings on display in 1796 now extant, the problems we faced in this historical reconstruction differed from our first. ${ }^{1}$

My team and I worked on this digital recreation with our eyes open to these challenges. As explained below, we filled in some of the unknowns with what we 
had learned about visitor flow and inherited museum practices from our prior reconstruction of the 1813 exhibition-which took place in the same architectural space. The Shakespeare Gallery was, after all, the original occupant of number 52 Pall Mall, which became home to the British Institution after Boydell's death. We were therefore also able to reuse the architectural SketchUp model developed for our first project, redecorating it to match Wheatley's 1790 sketch-just as our initial 1813 reconstruction had been guided by Thomas Rowlandson's 1808 image of the British Institution interior.

The current home page of What Jane Saw will soon make room for the Shakespeare Gallery, so that a visitor can time travel to 1796 or 1813 through the same e-portal. Specifically for $A B O$ readers, who were also the first to hear of the original What Jane Saw project (http://scholarcommons.usf.edu/abo/vol2/iss1/13/), I share here a few preliminary observations about the unexpected illumination of female participants in Boydell's decidedly male-dominated gallery. Boydell's capital-intensive Shakespeare project, which involved dozens of male artists and much swaggering bravado in Georgian newspapers and dining rooms, was heavy on the testosterone. Histories of the gallery have stressed the well-documented involvement of its flashiest and best-known participants, particularly Fuseli and Reynolds. While our visualization also aims to contribute to ongoing studies of these important male artists, an account of what our reconstruction process revealed about female artistry might be of particular interest to $A B O$ readers.

Strictly speaking, the gallery in 1796 involved commissions from only three female artists: Angelica Kauffman (1741-1807), creator of two paintings; Anne Seymour Damer (1749-1828), sculptor of two stone reliefs; and Caroline Watson (1760/1-1814), stipple engraver hired by Boydell to transform two canvases into folio plates. ${ }^{2}$ To the extent that talented female artists had been allowed to rise in their professions to positions that Boydell deemed commensurate with his ambitious project, it would appear that The Shakespeare Gallery was an equal opportunity employer, because Boydell's payments to Kauffman and Watson (payments to Damer go unrecorded) suggest equity for women artists when measured against male colleagues. ${ }^{3}$ In spite of this fiscal equity, female participation in the arts had unexpected utterances and gendered consequences when we visualized the gallery's 1796 appearance in our digital model.

Because prior discussion of gendered displays in Boydell's gallery has focused on the female heroines from Shakespeare depicted in the paintings, this essay will not retrace that same territory. ${ }^{4}$ I would, however, like to correct one prominent assumption that, in turn, impacts the identification of female participants in the gallery. Many historians assume that the heroines on the walls of the gallery were 
portraits of famous actresses. While universally tempting, this assumption is not supported by the facts. Although the 1813 Reynolds retrospective actively traded on an emergent celebrity culture, Boydell explicitly instructed painters not to use cameos of celebrity actors or actresses in commissioned pictures for his gallery. Celebrity portraiture, or indeed any reference to contemporary theater, was officially shunned in favor of history painting's powerful universality. One 1788 reviewer warned how the new Shakespeare Gallery might disappoint celebrity spotters: "it would not have been amiss had Messrs. Boydell advertised us that their first instruction to their artists was to forget, if possible, they had ever seen the plays of Shakespeare as they are absurdly decorated in modern theatres, and by no means to adopt ideas of ornament or attitude from any living manager or performers of either sex ..." (qtd. in Vickers 506). With this set of instructions, Boydell hoped to seal his history-painting spectacular off from live-action Shakespeare.

History painters did, of course, use live models. Sir Joshua Reynolds, for example, hired a laborer to sit for his famous picture of a dying Cardinal: "He had now got for his model a porter, or coal heaver, between fifty and sixty years of age, whose black and bush beard he had paid for letting grow" (Mannings 1: 525). Yet a sitter's anonymity safeguarded the universality of the resulting image. In the case of George Romney's muse, Emma Hart, a model's growing fame during the project's long tenure had the potential to eventually complicate history painting's simple realism. Emma's serendipitous role in safeguarding one painting from oblivion is discussed below.

Our digital visualization complements the paper scholarship of others. Historians have long acknowledged the cultural importance of The Shakespeare Gallery and tracked its influence on Shakespeare reception by means of the Boydell edition, engravings, surviving catalogs, and print reviews. The bulk of that book-based scholarship, however, has looked backwards upon the gallery through the lens of its end-products - constructing an idea of how the space looked at its close through the accumulated illustrations in the 1803 elephant folio of the plates or the 1805 Christie's sale catalog of Boydell's closing inventory. When paintings are reproduced as printed illustrations in these discussions, they become part of yet another book. Our digital reconstruction, which shows the gallery in full flower in 1796, makes visible the substantial difference between encountering these images in a paper volume (whether as lists, illustrations, or engraved folio plates) and viewing them as an exhibition of paintings on walls (even if those walls must be virtual). 
One thing that cannot emerge from an isolated reproduction or the monochromatic uniformity of Boydell's original engravings is the startling stylistic variety that hung in this gallery. Giant canvases by painters of renown hung cheek by jowl with works by relative unknowns and even illustrators who were, professionally speaking, considered mere jobbing artists. Members of the Royal Academy of Arts shared Boydell's walls with non-members. Women shared the space with men. The gallery's daring combination of artists and styles was both exciting and unnerving in a democratizing context that already mixed the ambitions of history painting with a populist interest in William Shakespeare (who did not yet carry the highbrow label he does today). Added to this was the mix of comedy and tragedy in the choices of scenes for the paintings. One critic surveyed Boydell's mash-up with diplomacy: "such a variety of subjects, it may be supposed, must exhibit a variety of powers; all cannot be the first; while some must soar, others must skim the meadow, and others content themselves to walk with dignity" (qtd. in Friedman 73-74).

Since a reader will wonder how we settled on the curatorial hang for 1796 in the absence of any records of the Shakespeare Gallery's interior layout, I add a brief paragraph about our visual logic. A much fuller explanation will be provided on the final site's “About" page. In sizing lost paintings, we relied upon comparable commissions, surviving fragments, and payment records, creating templates that took all known factors about a painting into account before trying to place it on a wall. In hanging the show, we followed the chronology of the paintings as numbered in Boydell's own annual Catalogue from 1796, a book-length guide used by visitors that indexes each picture and lists the name of the artist, identifying also the title, act, and scene of the relevant play. Boydell's Catalogue also includes text by Shakespeare of the scenes depicted in the paintings. We matched these numbered catalog entries to Boydell's folio engravings and, where possible, to surviving paintings. We know that every show held by the British Institution at 52 Pall Mall began at the North Room's North Wall. This starting wall for all exhibitions was dictated by the orientation of the central staircase which visitors ascended to the upper gallery. We therefore assumed the same starting point for the Boydell exhibition and also held to the same clockwise visitor flow recorded through each room for later shows. From there, wall space controlled much of our process, since fitting 84 paintings in numerical sequence into the three connected rooms of the Shakespeare Gallery could only be accomplished if they were packed in tightly. The resulting hang-the crowding differed radically from the look and feel of the elegant Reynolds retrospectivesurprised us. We hope that by showing two profoundly distinct exhibition styles in the same architectural space-one dated 1796 and the other 1813-cultural historians can use our site to track changes in aesthetics and curatorial practices. 
The aggregate nature of The Shakespeare Gallery, which has been studied and discussed for 200 years without so much as a diorama in a shoebox for common reference, has forced upon critics a false sense of chaos and confusion. Just because the pictures altered annually in order and arrangement during the gallery's fifteen years of operation (annual changes that are scrupulously documented by extant catalogs for most years of operation) that does not mean the chronology of the paintings was erratic or random during a single museum season that lasted from May through August. ${ }^{5}$ The numbering of the 84 pictures in the 1796 Catalogue reflects, we strongly believe, that particular year's inventory of paintings and the chronological order in which they were displayed on the gallery walls-not just because this proved true for 1813, but because Boydell sold his catalogs as helpful guides to visitors. While a static visualization such as ours cannot solve for the many possible arrangements across all fifteen years of the gallery's operation, we believe that we have "frozen" the gallery precisely as it looked in 1796.

The following preliminary observations about Boydell's deployment of female talent and reputation are only partially visible through a paper lens. Our digital visualization process (and the foundational research behind it) brought these issues unexpectedly into focus. Indirectly, these local insights show our methodology and assumptions in action while, directly, they sample what might be gleaned when digital tools serve historical scholarship in the humanities.

\section{Angelica Kauffman's sensational commissions}

Of the 84 large paintings on display in the upper rooms of Boydell's gallery in 1796, Angelica Kauffman painted two. Her "Two Gentlemen of Verona, 5.3" was commissioned as early as the planning year of 1788 , for $£ 210$. Subsequently, she also painted "Troilus and Cressida, 5.2," which earned her the identical sum of $£ 210$. Both paintings were engraved by Luigi Schiavonetti, who received $£ 315$ each for engravings published in 1792 and 1795, respectively. While these fees may strike us as horribly unequal ( $£ 210$ to the painter versus $£ 315$ to the engraver), the differential is not due to gender. Kauffman's and Schiavonetti's fees are perfectly in keeping with the routinely larger payments given to engravers by Boydell. Copper-plate engravings, it seems, not only took longer to produce than paintings but were more valuable to Boydell than canvases that, commercially speaking, merely advertised his prints and illustrated edition. The entire art gallery was a promotional scheme for products on paper, with the art of engraving at its center. 
Let us compare, instead, the prices for two Troilus and Cressida paintings, one by George Romney (it shows scene 2.2) and the other by Kauffman (scene 5.2). From a surviving fragment, we calculated that Romney's canvas was virtually identical in size (a little bigger, actually) to Kauffman's surviving painting, yet it only earned him $£ 105$. Kauffman, a member of the Royal Academy, received twice that sum for her picture. In both cases, the engravers received $£ 315$ each for translating them to copper plates. Without question, Kauffman received equity in pay as measured against male painters of similar rank (although, unlike Romney, she was not awarded any of the flashier commissions for upsized pictures). For pictures similar in size, painters who were not members of the Royal Academy routinely earned only half her fee, including Josiah Boydell, who does not appear to have taken advantage of his special ties to management.

Kauffman's Two Gentlemen of Verona sold for an unremarkable $£ 64$ at auction in 1805, and her Troilus and Cressida for $£ 73.10$. While these numbers are mere fractions of Boydell's original costs, they were fairly decent prices (top 10\%) for canvases from that disastrous May 1805 sale in which Boydell's entire stock was unloaded over three days at bargain basement prices. While most of these paintings simply disappeared after 1805, both of Kauffman's survive today in museums, implying that her two works continued to be protected and valued. Because Kauffman's two paintings survive, we know their exact sizes, which compare moderately to others in this Brobdingnagian gallery.

In these screenshots from our preliminary SketchUp model, you can find Kauffman's pictures in the top right hand corners of the long walls in the gallery's Middle Room. To give an idea of scale, both her paintings measure about $156 \mathrm{x}$ $222 \mathrm{~cm}$, making them just over 7 feet wide: 


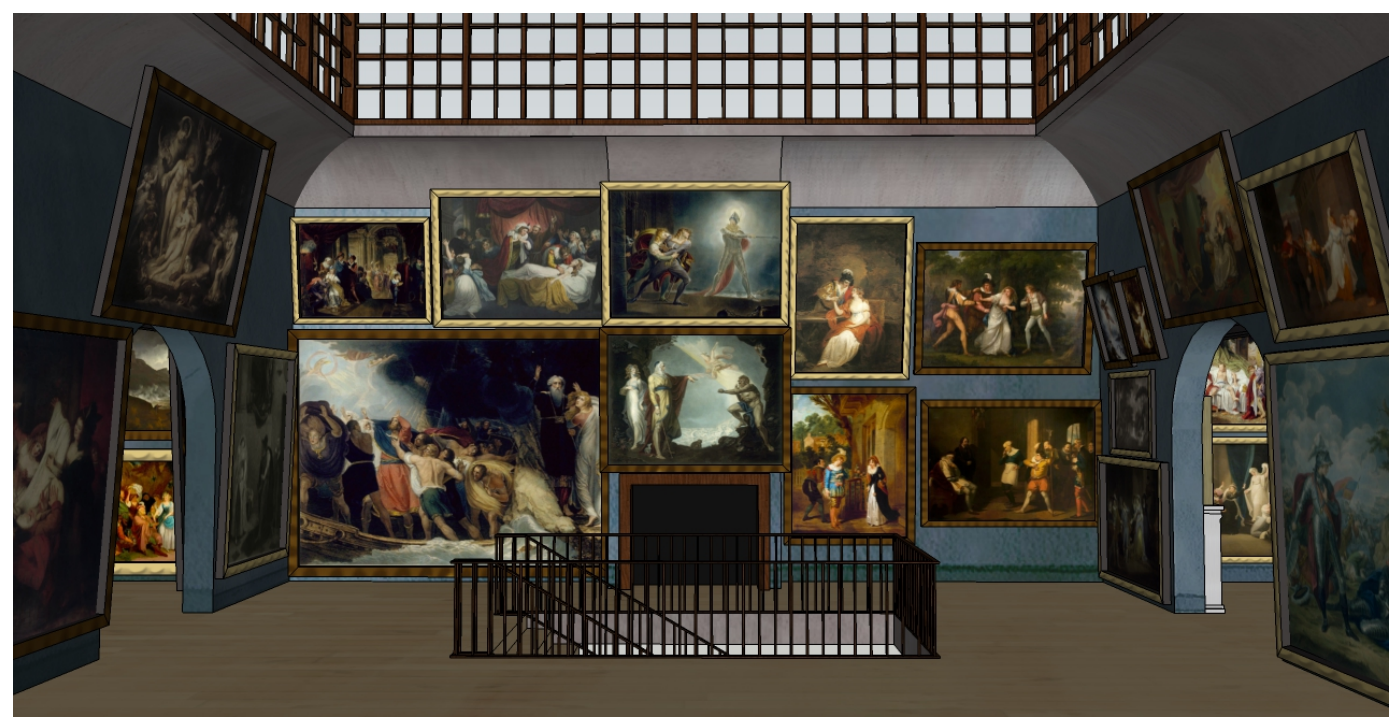

Figure 2: Screenshot of The Shakespeare Gallery's Middle Room East Wall, as it looked in 1796. SketchUp template of the What Jane Saw reconstruction.

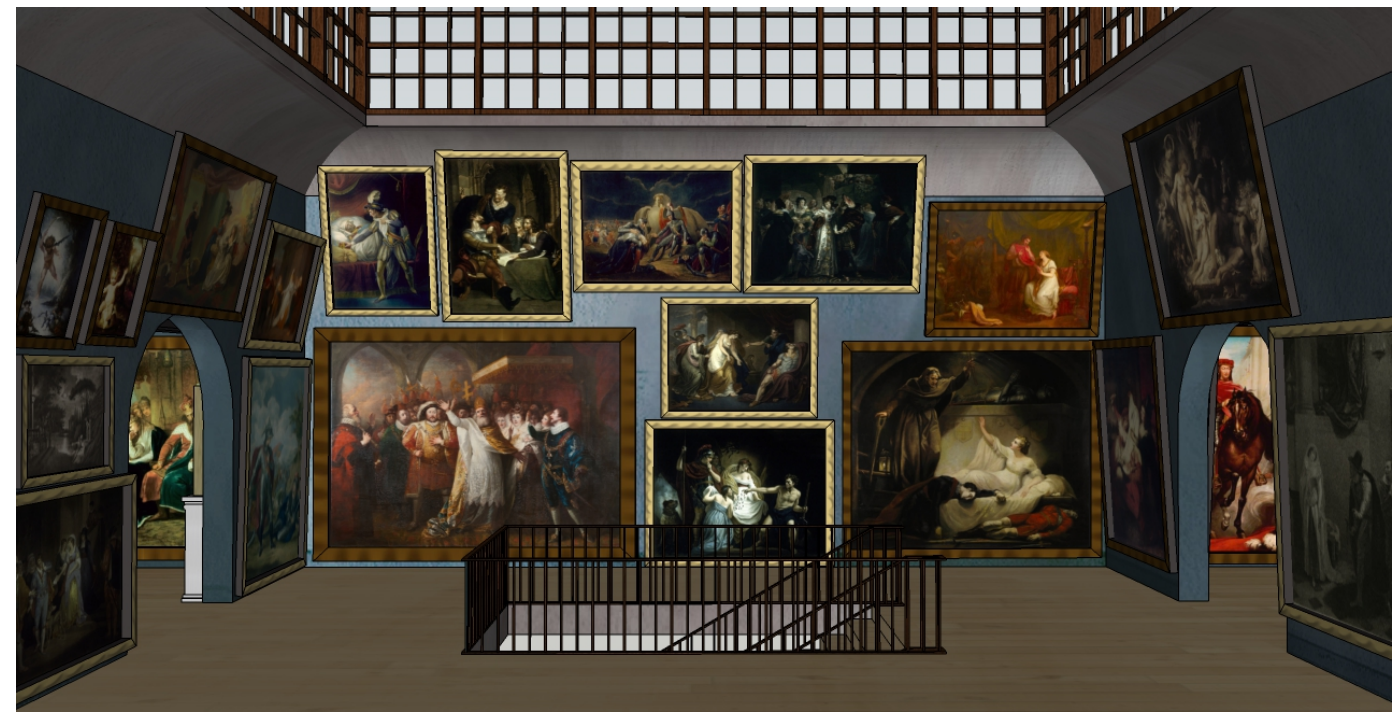

Figure 3: Screenshot of The Shakespeare Gallery's Middle Room West Wall, as it looked in 1796. SketchUp template of the What Jane Saw reconstruction.

The gallery's digital re-hang confirms that Boydell clustered paintings loosely by genre, or "species," a curatorial habit that Repton already remarks upon in The Bee in 1789. ' Kauffman's Two Gentlemen of Verona finds itself next to a romantic moment from The Tempest by Francis Wheatley (for which Boydell paid 
$£ 105)$ and above scenes from the Merry Wives of Windsor and Measure for Measure by Robert Smirke (his payments were also £105 each). On the wall opposite, Kauffman's Troilus and Cressida is, appropriately, part of a dramatic display devoted to history and tragedy. From a distance, with so many larger and more dazzling canvases, Kauffman draws no special notice in either corner. The printed catalog entries announce, "Painted by Mrs. Angelica Kauffman Zucchi, R.A." (Boydell, John, 1796, 80). Here is the partial entry for the first picture in the 1796 catalog: ${ }^{7}$

\section{No. XXXVIII. TWO GENTLEMEN. OF VERONA. ACT V. SCENE IV. A Forest. Valentine, Protbeus, Silvia, and Fulia. Painted by Mrs. Angelica Kauffman Zuc- $\mathrm{CHI}, \mathrm{R} . \mathrm{A}$. Enter Valentine. \\ Val. How use doth breed a habit in a man! \\ This shadowy desert, unfrequented woods, I better brook than flourishing peopled towns : Here can I sit alone, unseen of any,}

Figure 4: Detail from John Boydell, A Catalogue of the Pictures, \&c. in the Shakspeare Gallery, Pall-Mall (London, 1796), p. 80.

At first it seems as if, like Shakespeare's Valentine, Kauffman sits off to the side-participating in this art scene almost unseen. Her friendship with Sir Joshua Reynolds, her status as a founding member of the Royal Academy, and her reputation as a serious history painter combine to make her involvement in Boydell's project unremarkable, because logical. Boydell's gallery hoped to elevate history painting by yoking it to Shakespeare's rising star, involving the top names in the business. Angelica Kauffman was a big name. Less than a decade earlier, the craze for her work in London had made one European ambassador famously remark "the whole world is angelicamad" (Murray). Her residence in Rome during the gallery's years of operation further suggests that Boydell expended extra effort to commission her work, straining the project's emphasis on native genius with this inclusion of a Swiss-born artist living in Rome. ${ }^{8}$ Members of the public, kept informed of Kauffman's involvement in the 
gallery through newspaper notices, must have eagerly scanned the walls for her pictures among those by men whose names were far less familiar to them.

Kauffman's two pictures were celebrity commissions, yet her scene from Two Gentlemen has disappointed modern art historians as "distinctly undramatic" (Goodden). Nothing about this painting stands out until one draws closer and considers both its contextual hang, ringed by romance and comedy, and its subject in conjunction with the artist's fame and gender. For, upon closer examination, it proves that Kauffman's painting shows an attempted rape:

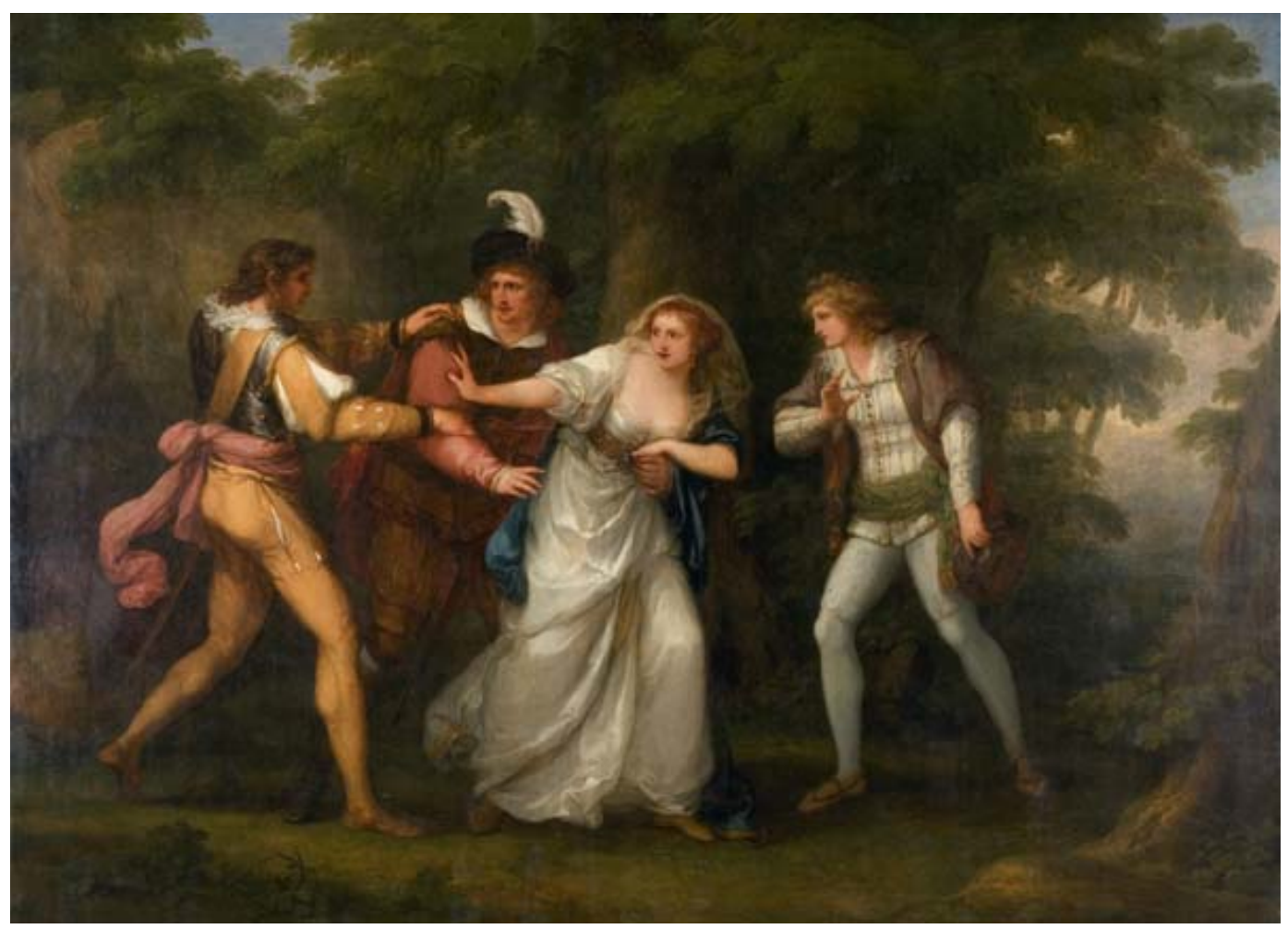

Figure 5: Painter: Angelica Kauffman Zucchi, Two Gentlemen of Verona. Oil on canvas. Size: $156.8 \mathrm{~cm}$ x $221 \mathrm{~cm}$. Davis Museum and Cultural Center, Wellesley College.

The viewer, then as now, need not have recognized the scene at a glance. For a shilling, a Boydell gallery visitor had been armed with a handy volume of corresponding Shakespeare passages. In this catalogue-cum-anthology, the printer isolates in italics "the point of Time chosen by the Painter"- the precise moment at which the action of a scene is suspended by the painter (Boydell, John, 1789). Our finished website will provide the modern visitor with corresponding 
facsimiles from Boydell's original 1796 catalog for each painting. For Kauffman's scene, the italicized moment begins with Silvia's realization that Proteus means to rape her: "O heaven!" Proteus threatens, "I'll force thee yield to my desire." This is when Valentine, Silvia's betrothed, emerges from his hiding place to protect her against his best friend: "Ruffian, let go that rude uncivil touch; / Thou friend of an ill fashion!" It is the dramatic dissolution of their friendship that, also rendered in italics, ends the printed scene offered by Boydell as the picture's soundtrack.

Sil. $O$ beaven!

Pro. I'll force thee yield to my desire.

Val. Ruffian, let go that rude uncivil toucb;

Thou friend of an ill fasbion!

Pro. Valentine!

Val. Tbou common friend, that's witbout faitb or love

(For sucb is a friend now); treacberous man!

Thou bast begruil'd my bopes; nougb: but mine eye

Could bave persuaded me: Now I dare not say

I bave one friend alive; thou would'st disprove me. Who sbould be trusted, when one's own right band

Is perjur'd to the bosom? Protbeus,

I am sorry, I must never trust thee more,

$B$ ut count tbe world a stranger for thy sake.

The private wound is deepest! O time, most accursi!

'Mongst all foes, that a friexd should be the worst!

Figure 6: Detail from John Boydell, A Catalogue of the Pictures, \&c. in the Shakspeare Gallery, Pall-Mall (London, 1796), p. 82.

This may be a scene from a Shakespeare comedy, but it is not a comic scene-not even in an eighteenth-century context, a time when Londoners were amused by captive cats in boxes played as "Cat-Organs" and other low spectacles now deemed cruel. When compared to Smirke's canvas of another "villainous plot" from a comedy, namely the subplot to wrongly accuse Hero in Much Ado, Kauffman's scene lacks what Repton identifies as the "natural humour" of the Smirke painting, which he likened to the style of Hogarth (20). ${ }^{9}$ Kauffman's composition shows four personages, including an androgynous Julia dressed as a boy named Sebastian. What in Kauffman's wooded scene looks at first glance like three men assaulting a distressed young woman proves, reading from left to right by the light of Shakespeare's text, two men and two women. The shock of recognition that draws the gallery viewer first towards the potential tragedy and 
criminality of rape and then back again to the safety of Silvia's rescue (and the mitigating presence of Julia) is pure sensationalism.

Although images of women in the gallery abound (tragic and comic, romantic and repulsive, clothed and not), Kauffman's Silvia is the only woman on its walls suspended during the danger of sexual violence. One painting by book illustrator Thomas Kirk does show a victim of rape, namely Lavinia from Titus Andronicus. Not only is Lavinia shown long after the crime, but Kirk hides the stumps where her hands were cruelly dissevered with a great amount of drapery, minimizing the violence central to Shakespeare's scene and, as Repton observes, thereby "render[ing] the story more obscure." Repton's critique of Kirk's painting also applies to Kauffman's, which was not yet on display when he published this review in 1789: "When we know the story, it becomes disgusting; and till we know it, there is little interest excited" (46). The muted softness of Kauffman's own scene - the Italianate landscape, pastel palette, and (again) the emphasis on fabrics in movement-similarly masks violence and does not garner much notice until the indelicacy of her assigned subject is unmasked in the context of the public gallery. Those who dismiss Kauffman's canvas as bland have not stood before it in its original context, Catalogue in hand, to experience what Repton describes as the disgust of recognition.

The curatorial placement of Kauffman's painting in 1796 remains troubling: does the hang risk decriminalizing rape by treating this scene as a subject of comedy, or does Boydell's curatorial strategy stress Silvia's dangerous predicament through a jarring juxtaposition with a comic surround? Either way, Boydell achieves controversy. In truth, his gallery was criticized for being sensationalist in the choice of Shakespeare scenes. A 1791 review complained that "In the choice of their subjects the painters of the Gallery have been naturally led to adopt the excesses of horror, extravagance, vulgarity, and absurdity ..." that the reviewer then goes on to attribute to Shakespeare himself (Vickers 509). Excesses were a great part of the gallery's attraction-the binge-watching equivalent of consuming all of Shakespeare's highlights in one powerful go.

It is not known how much input painters had in their choice of subjects. Applying Occam's razor, scholars agree that Boydell must have assigned his many artists specific scenes to avoid duplication or uncomfortable comparison. Not only had Kauffman's attempted rape scene from Shakespeare never been previously approached by any illustrator, the fact that a celebrated female artist executes it adds further piquancy to the picture's shock value. ${ }^{10}$ 
In Kauffman's second commission, Cressida holds the hand of Diomedes inside a tent, while an enraged Troilus, restrained by Ulysses, looks on from outside. To put it another way, the two subjects commissioned from the only participating female painter in this grand public spectacle are rape and infidelity, gendered crimes committed against and by women. Suddenly, John Boydell looks a lot more like Edmund Curll, Grub Street's ultimate provocateur who made the byline "by a Lady" central to many a titillating (and effective) marketing strategy.

In sum, our visualization of the gallery shows how Boydell subtly exploits Kauffman's gender by, first, commissioning from her a depiction of sexual assault and then hanging it not among the gallery's many instances of violence (there is no shortage of murder or infanticide) but in a deceptively comic corner shared with comparative lightweights such as Wheatley and Smirke. Just imagine being a gallery visitor who, standing before this grouping of paintings and reading merrily along with the Catalogue, suddenly realizes that the true subject of this picture by an illustrious lady artist is attempted rape! ${ }^{11}$ This startling choice of scene for Boydell's sole female painter need no longer go unremarked.

\section{Anne Damer's stone works and gendered brand}

While our visualization showed the famous Kauffman tucked deceptively into corners, the lesser-known sculptor Anne Seymour Damer emerged as a prominent focal point. Most obviously, Damer is distinctive among Boydell's artists for working in the medium of stone. Although a large sculpture of Shakespeare commissioned from Thomas Banks greeted visitors in the downstairs vestibule, Damer was the only non-painter showing in the main gallery in 1796. Her two "BASSO-RELIEVOS," with scenes from Coriolanus and Anthony and Cleopatra, are given their own section in the catalog, between the large "Pictures" upstairs and "SMALL PICTURES" on the ground floor (Boydell, John, 1796, 181 and 183). Boydell rearranged and swapped out artworks annually, refreshing his gallery every museum season, and Winifred Friedman quotes from an earlier newspaper report describing the Coriolanus relief "exhibited over the chimney piece of the center room" just after its arrival in 1790 (197).

In our hang, we followed the strict chronology of the 1796 catalog and were surprised when Damer's two pieces gained pride of place on the concluding wall in the main gallery, along with George Romney's "The Infant Shakspeare, Attended by Nature and the Passions." Romney's is the only picture that does not offer a scene from a play and gets special numberless treatment just ahead of the catalog entries for Damer. We interpreted this unusual trio as a transitional grouping that signaled an end to the upstairs picture experience and sent visitors 
back downstairs for viewing of the ground floor rooms and museum shop (yes, there was a downstairs shop!).

One practical problem was sizing and positioning Damer's two untraced stone pieces for which there are no other precedents in the gallery or, indeed, anywhere but in the Acropolis-her apparent inspiration. With no recorded sizes or comparables among Damer's surviving sculptures, we were forced into educated guesses. The only remaining record of these two pieces proved Boydell's own engravings, which he used as vignettes on the title pages to his folios (another clue to his view of them as prominent showpieces). Boydell's detailed prints proved as effective as photographs and, calibrating our sense of size against the scale of other Damer works and the classical reliefs she might have known from her travels, we decided to make them as wide as the space on either side of the archway allowed. Above the arch we hung Romney's "Infant Shakspeare," which survives in the Folger Shakespeare Library. Romney's portrait of the poet as a naked infant, surrounded by attendants in the manner of Christ's nativity, seemed a fitting and playful end to the gallery's operative Bardolatry.

After our first pass at the hang of this wall's layout, however, it looked bare compared to the others: the Romney was just a tad too small to fit proudly over the archway and the Damer pieces, even at their maximum width allowed by the space, too diminutive to take command of the space. Elsewhere in the gallery the archways were flanked by taller paintings, or more works. Facing us was an unsettling amount of bare wall. We started to wonder if some "Small Pictures" had hung upstairs after all.

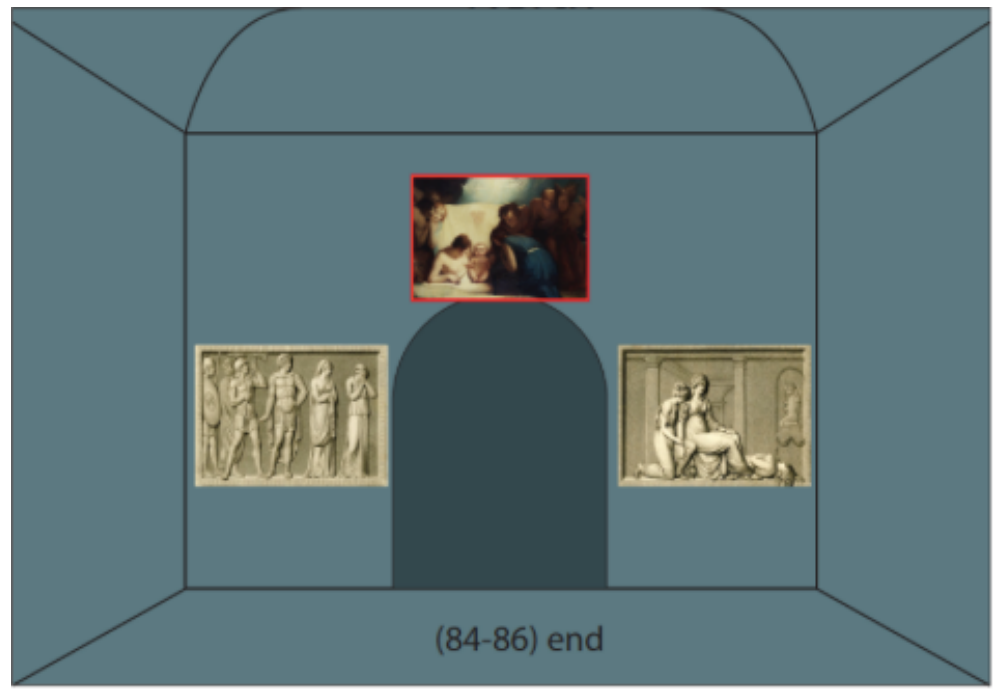

Figure 7: Screenshot of trial layout in SketchUp of South Room North Wall. 
A little more digging exposed two pieces of data we'd missed in the enthusiasm of our initial pass. First, a conservator's report at the Folger revealed that the surviving Romney canvas had been significantly trimmed at some point in its history. By comparing the corresponding Boydell engraving, we could speculate about how much bigger the original composition might have made the untrimmed painting. Accordingly, we digitally stretched, as it were, our Romney canvas (we did not want to trade the splendid color image for a black-and-white engraving).

Second, it is a truth universally acknowledged that heavy sculptures made of stone cannot be hung on a gallery wall by a mere nail or piano wire but must be supported by a base. In manipulating our digital model we'd momentarily neglected gravity. To correct this, we fussed over how these heavy stone reliefs might have been supported (surely they'd have looked silly just sitting on the gallery floor?) and settled on digitally manufacturing a suitable base-something non-permanent that Boydell might have had constructed. Here are some options we pondered, along with wall color tests.
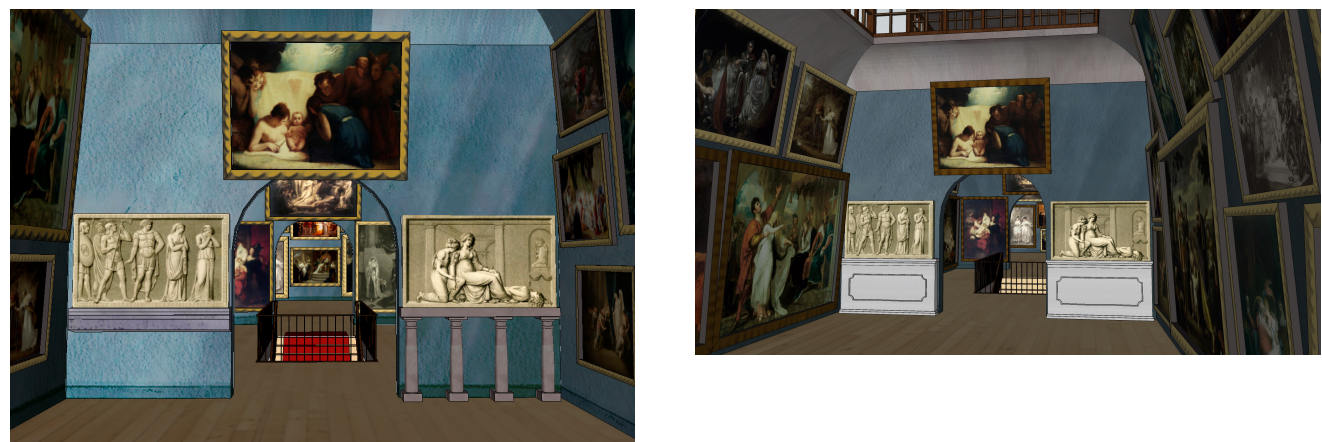

Figures 8a and 8b: Screenshot of trial layouts in SketchUp of South Room North Wall.

We opted for the choice on the right. The resulting layout, with the plumper Romney over the archway and unadorned marble supports for the Damer reliefs, proved more balanced-ending the experience of the upper gallery with a hint of drama.

With his catalog entries for "The Honourable Mrs. Damer," Boydell flags the gender of an artist who, by virtue of working with hammer and chisel in imitation of classical sculptors, was (forgive the pun) the butt of sexist jokes in 1789 when the gallery opened-including this cartoon, "The Damerian Apollo." 


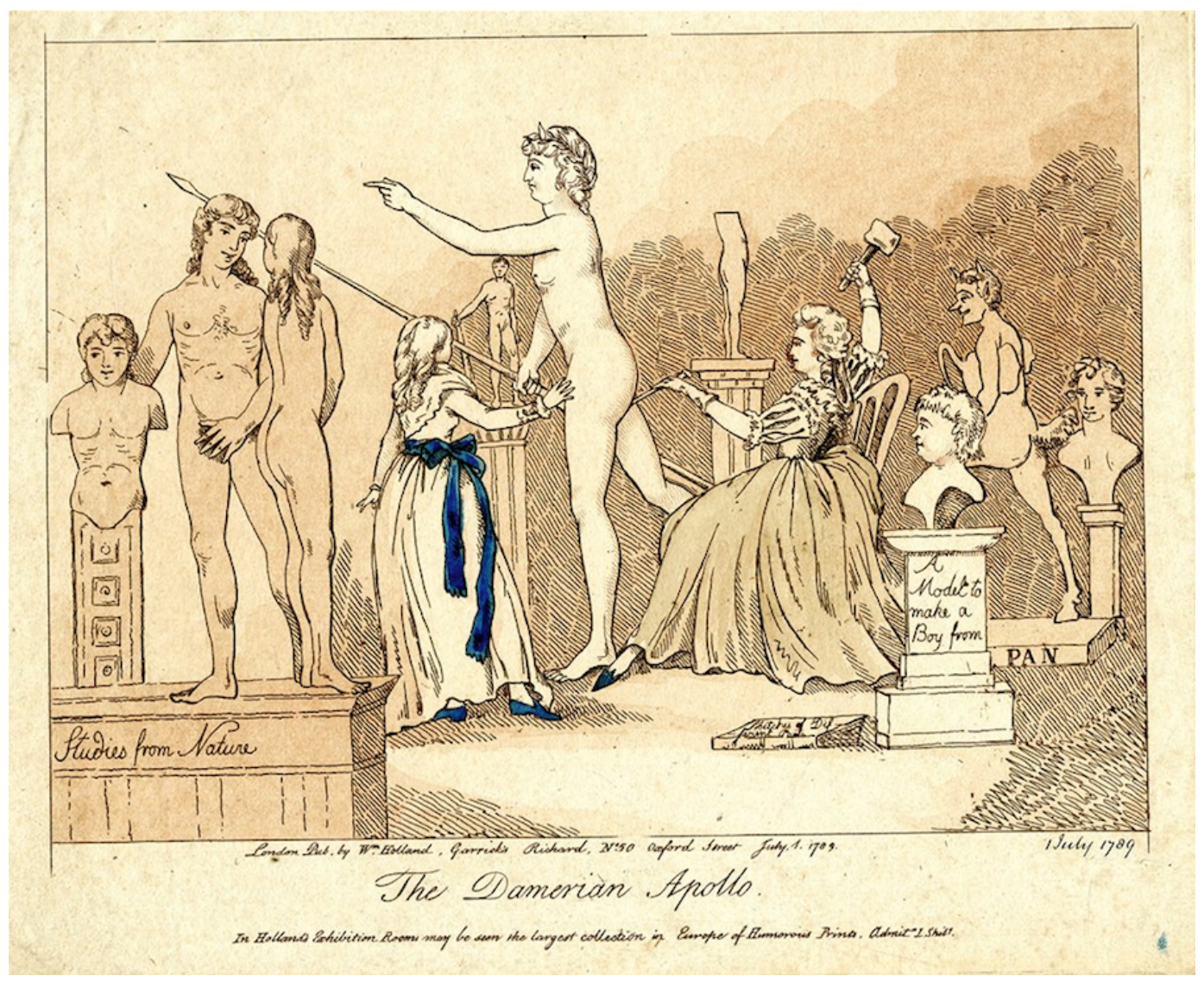

Figure 9: "The Damerian Apollo." (London: Published by William Holland, 1789). British Museum. URL: http://www.britishmuseum.org/research/collection_online/collection_object_detai ls. aspx ?objectId=1462301\&partId=1\&searchText=damerian+apollo\&page $=1$

Eager to coopt the power of contemporary artistic controversy for his own ends, Boydell steps away from the gallery's emphasis on history painting to allow Damer's stone works special prominence. True, Damer's high-profile participation is also evident in paper form, where her art appears as vignettes on the title pages to the two-volume elephant folio of his engravings. In the space of the gallery, however, Damer had the honor of closing rather than opening the exhibition; her stone reliefs become the main galleries' lingering afterimages. Although the pediments in our visualization are, we acknowledge, merely an interpretation or approximation, only a recreation of the exhibition space can show how emphatically Boydell confronted his visitors (not just elite subscribers to the final engravings) with Damer's unusual species of art. As a woman working in a man's profession, Damer became a unique brand among sculptors by trading 
on her gender. Irrespective of her talents, Damer caught the public eye because she was a curiosity. Boydell proves willing to break his operative commitment to history painting to harness that gendered curiosity to his commercial enterprise.

\section{The contributory celebrities of Emma Hamilton and Mary Wells}

Ironically, although Boydell shunned portraiture in his Shakespeare Gallery, the celebrity of one model safeguarded a portion of an important picture. In addition, the strange legacy of provocative female artistry in this gallery may include Georgian performance art.

One of the problems our reconstruction faced is that more than half of the paintings displayed in 1796 are untraced and thought destroyed. The scale of many Shakespeare Gallery paintings, combined with their low sale prices at auction in 1805, appear to have been detrimental to their survival. Too large for most living spaces, some were cut down-or even cut into multiple smaller pieces to isolate individual figures. Mapping surviving fragments onto the full composition to which they belong provided one way of calculating the original dimensions of lost paintings.

George Romney's Troilus and Cressida 2.2 enjoyed such pride of place in 1796 at the far South end of the gallery as to make it a focal point through the arches (it is the same reigning spot on the far South wall that Reynolds' portrait of Queen Charlotte occupies in 1813). We did not manipulate the digital hang so as to create this effect. Only after crowding all the pictures in their 1796 catalog sequence to fit into the three rooms-following the same clockwise visitor flow as the 1813 show-did we see Romney's Cassandra raving at us through the arches. Because we were using a colored engraving as a stand-in for the lost painting, I did not recognize Romney's model at first. 


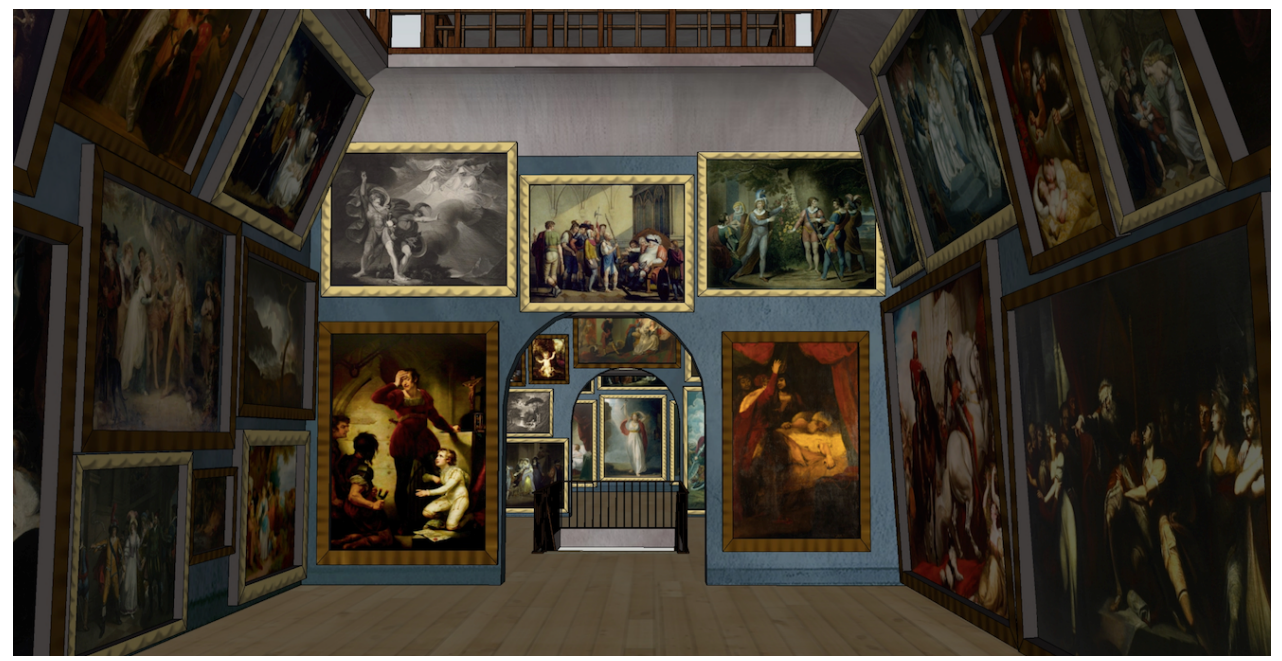

Figure 10: Screenshot of The Shakespeare Gallery's as it looked in 1796, viewed from the top of the North Room through the arches towards the South. SketchUp template of the What Jane Saw reconstruction.

Then, a large portion of the canvas came to light in the form of a fragment that survives in private hands as "Lady Hamilton as Cassandra." 1929 records this fragment's dimensions as $129.54 \times 93.98 \mathrm{~cm} .{ }^{13}$ Here is that fragment superimposed on the colored print in our e-gallery, providing aspect ratio:
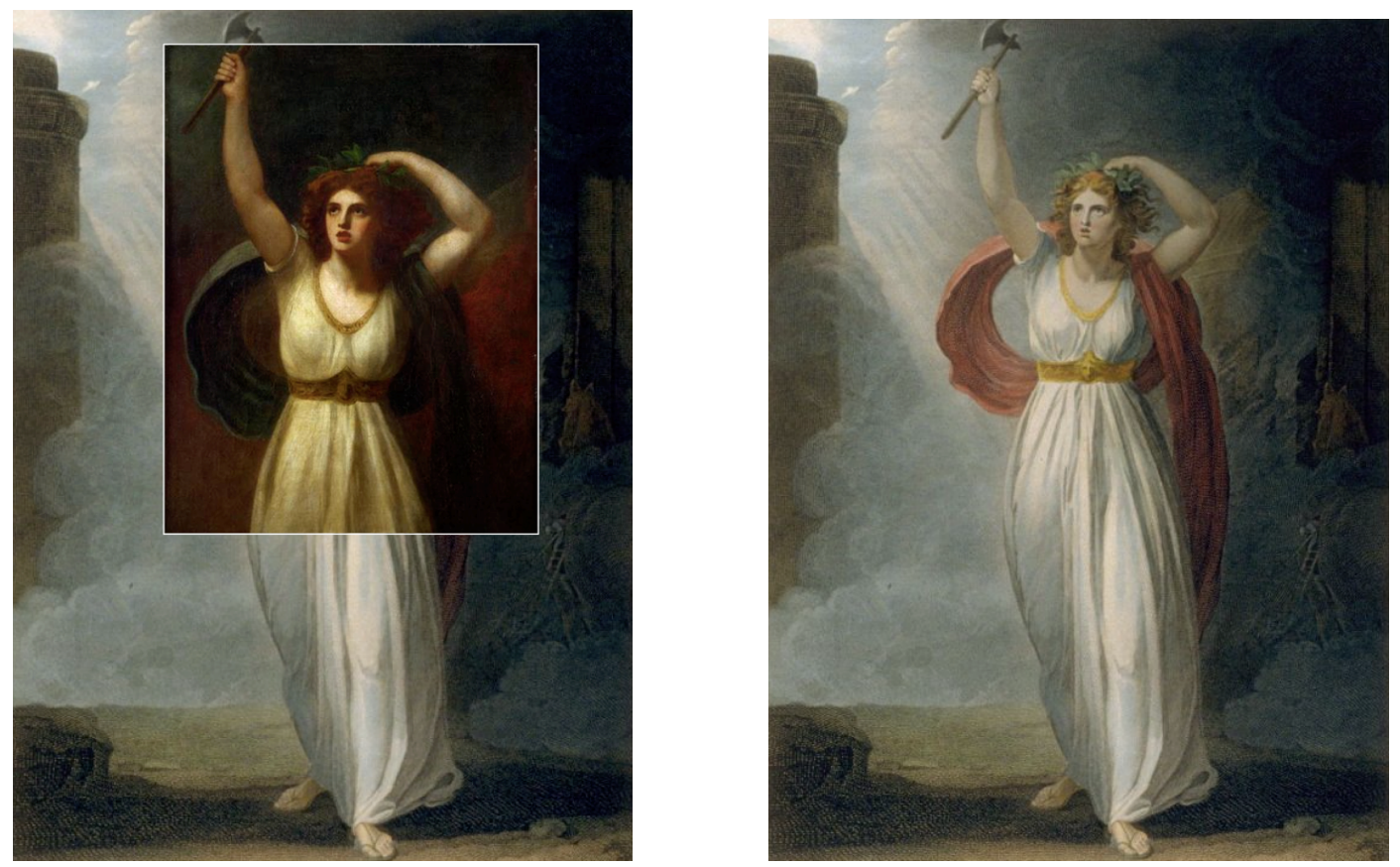
Figures 11a and 11b: Remnant of George Romney, "Troilus and Cressida 2.2" imposed upon a hand-colored engraving of same by Francis Legat, first published 1 Jan. 1795. Remnant: "Lady Hamilton as Cassandra" is in private hands (129.54 x $93.98 \mathrm{~cm})$.

Engraving: Fine Arts Museum of San Francisco. URL:

http://art.famsf.org/george-romney/troilus-cressidaact-ii-scene-ii-19633019979

With this simple imposition, calculating the original size from a fragment becomes rudimentary mathematics. Not only does the picture's full size tantalizingly match our estimates of the life-sized original, but Emma Hart's subsequent celebrity as Lady Hamilton (her high-profile affair with Nelson began in 1798) explains why someone after the 1805 Christie's sale would take a knife to a Boydell-by-Romney because they valued the likeness of the model more than the historical context of Shakespeare's scene. Or, putting it more generously, because someone after 1805 recognized Emma, a substantial portion of this picture was saved.

In addition to providing welcome data to reinforce our sizing estimates for lost paintings, such fragments make it easier to imagine the style and glory of larger lost pictures, demonstrating that colored prints and copies remain unsatisfying substitutes. Sadly, the existence of each fragment (so far, we've traced seven, from four different pictures) also confirms that the original from which it was cut remains permanently lost, ending all hope that it has been merely lying neglected in some attic corner.

As the name of What Jane Saw (www.whatjanesaw.org) implies, Jane Austen remains the focal lens of this digitally reconstructed, Georgian-era, Shakespeare exhibition. Born in 1775, coming of age in the 1790s, and publishing in the 1810s, Jane Austen experienced William Shakespeare's rise to literary mega-stardom firsthand. She read his works, referenced him widely in her own fictions, and saw many of his plays performed. One of her earliest surviving letters is dated 23 August 1796 and was sent from an address on Cork Street, placing her within an easy ten-minute walk of Boydell's gallery. It seems inconceivable that her London relatives would not take the budding writer, avid thespian, and Shakespeare fan to see Boydell's famous gallery. Although no first-person account of such a gallery visit by Austen survives (a letter about seeing exhibitions in 1813 does), she remains our synecdotal avatar for thousands of eighteenth-century London sightseers who came to Boydell's Shakespeare Gallery during the season, from May through August. 
One of those other sightseers was fellow novelist Frances Burney, who comments on her first trip to Boydell's in 1792 in a letter to a friend. Burney, whom Austen admired and emulated, describes her visit as an "adventure" centered upon the ruckus of "a mad woman" soon identified as "Mrs. Wells, the actress," who "was certainly only performing vagaries to try effect, which she was quite famous for doing" (Burney, 2:275 and 276). Boydell's art gallery is, in Burney's letter, chiefly a site of emotional provocation and female celebrity. The specific provocateur in this instance proved actress Mary Wells (1762-1829), whose "excessive theatricality" was part of a cultivated public identity that teetered, rumor had it, on the edge of madness (Engel 5). ${ }^{14} \mathrm{~A}$ small drawing of her from 1792, the same year Burney encountered her at Boydell's, survives to give us a picture of what Fanny saw.

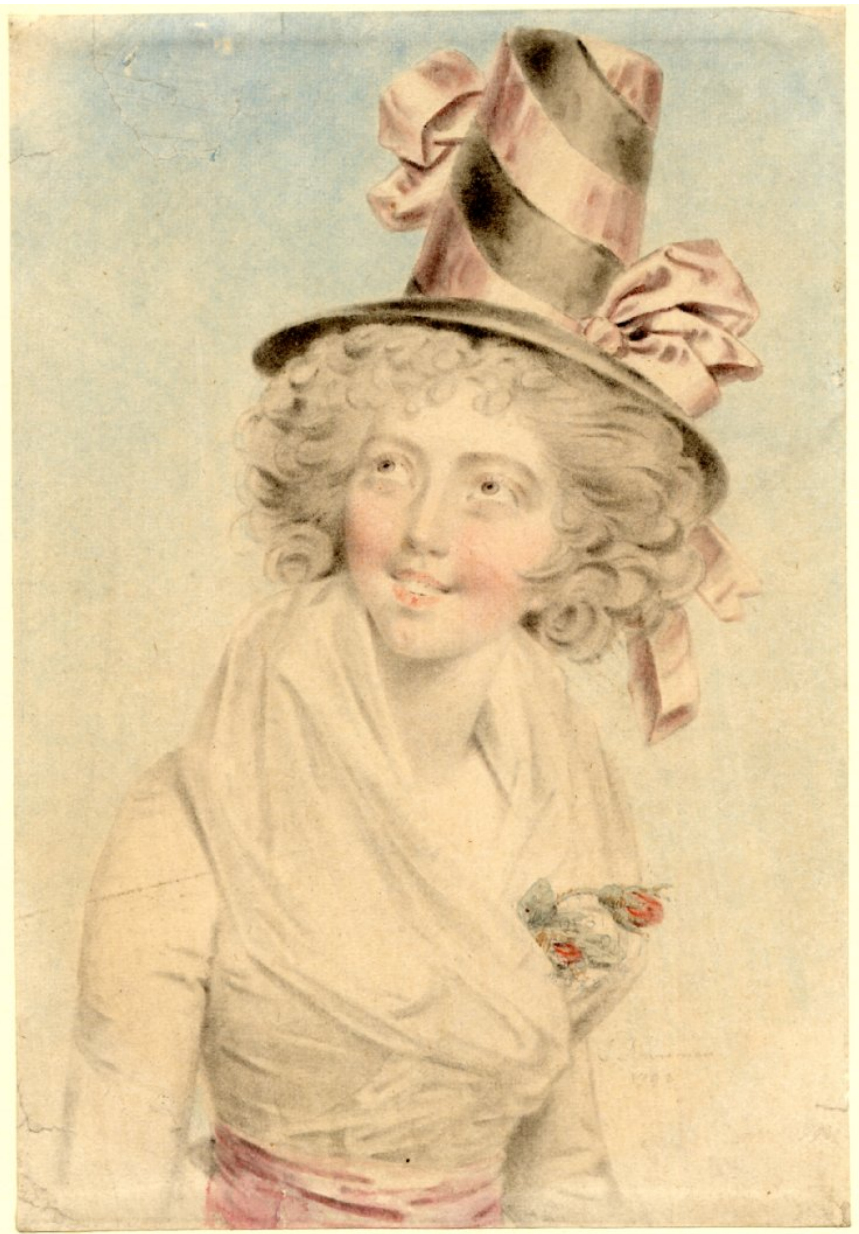

Figure 12: John Downman, "Portait of Mrs. Wells, actress" (1792). Chalk and watercolor on paper. British Museum. URL: http://www.britishmuseum. org/research/collection online/collection_object_ details.aspx?objectId= 748082\&partId=1\& searchText $=$ down man\&page $=1$ 
Rather than record the reactions of her companions to Boydell's artworks, Burney recounts their response to the dramatics of Mrs. Wells, synesthetically remarking on how their horror at the effrontery and "burlesque humor of a bold player" would be the perfect "food for a painter" (Burney 2:276). In Burney's story, Mrs. Wells outrageously follows visitors and stares them down, theatrically smelling a fake nosegay of silk flowers and mumbling things to make members of Burney's party uncomfortable.

Did Boydell's gallery exude such an aura of demonstrative display that it drew actresses eager to test their craft on its visitors? Or, given the other provocative and even uncomfortable showings of female celebrity in the Shakespeare Gallery, was Mrs. Wells on Boydell's payroll and this some clever publicity stunt? In the context of Boydell's artistic trifecta-Shakespeare, painting, and book illustration-Mrs. Wells was directly associated with the less-expensive Shakespeare editions of publisher John Bell. Unlike Boydell's history paintings, Bell's small-format illustrations embraced the celebrity of actresses, showing "Mrs. Wells" in several key roles. Here are two illustrations featuring the actress from Bell's cheap Shakespeare text after designs by Ramberg and Hamilton, artists whose canvases also hung in Boydell's Gallery:
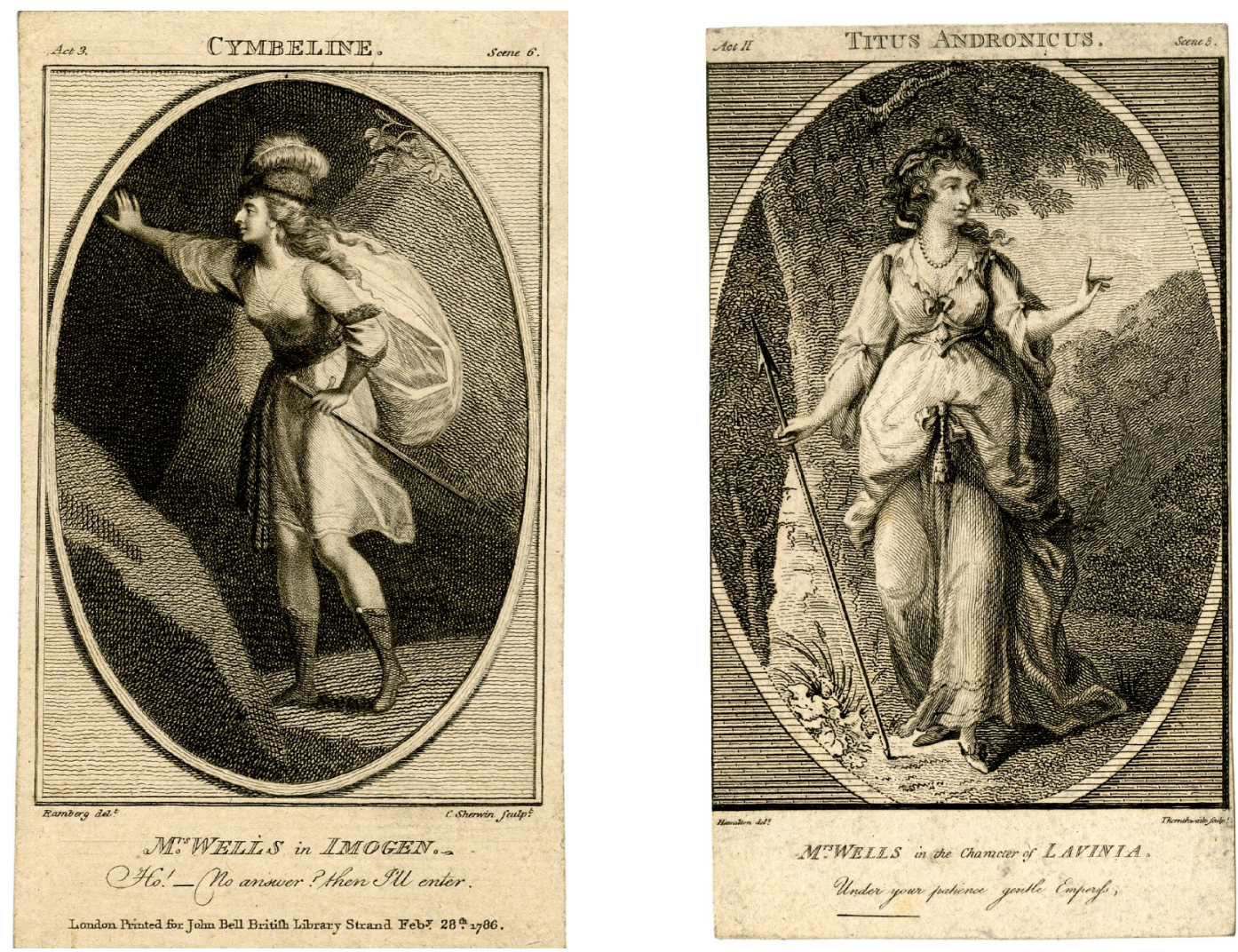
Figures 13a and 13b: Book illustrations to John Bell's Shakespeare. On the left, a portrait of the actress Mary Wells in character as Imogen (1786) and, on the right, as Lavinia (1785). British Museum.

URLS:

http://www.britishmuseum.org/research/collection_online/collection_object_detai $\underline{\text { ls.aspx } \text { ?objectId=3482753\&partId=1\&searchText=mary+wells\&page }=1}$

and

http://www.britishmuseum.org/research/collection_online/collection_object_detai $\underline{\text { ls.aspx?objectId=3314999\&partId=1\&searchText=mary+wells\&page=1 }}$

The art world, then as now, was small. With so much overlap between the talent pools of different Shakespeare projects, the edges of competition and cooperation are hard to define-what businesses today term coopetition. If Mrs. Wells called attention to herself in Boydell's gallery uninvited, she would have been guilty of trying to poach his brand to promote her own quirky celebrity. If Boydell gave Wells permission, or even payment, to make a spectacle of herself in his gallery, he would be extending his brand to include hers. Given Boydell's track record of slyly manipulating the celebrity of female artists (albeit with their knowledge, tacit permission, and profit sharing), my money is on active collusion.

\section{Acknowledgments}

The What Jane Saw project continues to be generously supported by Liberal Arts Instructional Technology Services at the University of Texas at Austin. I would also like to thank Heather McPherson and Kate Singer for their generous comments upon an earlier draft of this article.

\section{Notes}

\footnotetext{
${ }^{1}$ Humphry Repton authored a pamphlet review entitled The Bee; Or, A Companion to the Shakespeare Gallery, touted as "a catalogue raisonné" on its title page. It describes and comments only on the 34 pictures on display at the 1789 opening and does not record sizes.

2 Caroline's father was James Watson (1739-1790), a mezzotint engraver with a long history working for Boydell before the gallery project even launched. James Watson was well-respected, engraving at least fifty Reynolds portraits in his career. His death in 1790 may explain why the high-profile commission to engrave Reynolds's "Second Part of King Henry VI, 3.3" goes to his daughter Caroline.
} 
${ }^{3}$ See, Josiah Boydell's manuscript "List of paintings commissioned for the Shakespeare Gallery," in the Folger Shakespeare Library. All payment figures cited in this article are taken from this manuscript record. Although Caroline Watson falls on the low end of Boydell's pay scale for engravers, she was also lesser known in her craft. She is, however, generously awarded the high-profile commission to engrave a Reynolds picture (possibly because it had been promised to her father before his death). When she engraves "The Tempest, 5.1" by Francis Wheatley, Boydell pays her twice what he pays for the painting: $£ 210$ to her and $£ 105$ to Wheatley. Kauffman's payments, which are on the high end of the scale for painters, are discussed in more detail momentarily.

${ }^{4}$ For a good example on this topic, see Georgianna Ziegler's "Suppliant Women and Monumental Maidens: Shakespeare's Heroines in the Boydell Gallery." (http://shakespeare-gesellschaft.de/en/publications/boydell-catalogue/georgiannaziegler.html)

${ }^{5}$ For a meticulous account of the changes in Boydell's annual catalogues, see Ann Hawkins, the only scholar to have tracked shifts in the gallery's display by means of the bibliographical history of his extant catalogues.

${ }^{6}$ Dias observes that Repton's pamphlet may "have been commissioned by Boydell" as a puff piece (Dias 234, n88).

${ }^{7}$ The scene number is a misprint, one of four such in the 1796 Catalogue. Ann Hawkins convincingly suggests that all of Boydell's catalogues were sloppily printed, recycling bits from prior years, to keep costs low.

${ }^{8}$ As Rosie Dias points out, Boydell's cultural notions of what was "English" flexed to accommodate James Barry from Ireland, Henry Fuseli and Angelica Kauffman who were both Swiss-born, and Johan Heinrich Ramberg from Hanover, who is anglicized in the catalogs as John Henry (4).

${ }^{9}$ Repton's publication glosses only the 34 pictures that first opened the gallery in 1789, none of which were painted by Kauffman.

${ }^{10}$ Angelica Goodden asserts that "This scene had never been taken as a subject for illustration before (though Thomas Stothard and Francis Wheatley would attempt it after Angelica." 
${ }^{11}$ It was rumored that young Angelica had dressed as a boy in order to attend art school in Milan. This story may or may not have added to the frisson of the artist's own identity as a woman engaged in a man's profession, in this instance painting an image of sexual assault that includes a cross-dressing girl. Moore and Simpson repeat these rumors and, although they cannot verify them, deem such stories "quite possible" (26).

${ }^{12}$ A study for this painting also survives in the Tate as "Lady Hamilton as Cassandra" (http://www.tate.org.uk/art/artworks/romney-lady-hamilton-ascassandra-n01668). I initially mistook the Tate's study for a circular remnant, or cutout of the face, until the larger and more detailed piece turned up. As was his practice, Romney painted a number of studies that survive with variants of the same title, but only this fragment matches the precise composition of Boydell's engraving to provide aspect ratio of the lost original.

${ }^{13}$ See http://artsalesindex.artinfo.com/asi/lots/3266903

${ }^{14}$ See also Engel chapter 3: "Mary Wells's Notorious Celebrity."

Works Cited

Boydell, John. A Catalogue of the Pictures in the Shakspeare Gallery, Pall-Mall. London, 1789. Eighteenth-Century Collections Online. Web. 10 Mar. 2015.

----. A Catalogue of the Pictures, \&c. in the Shakspeare Gallery, Pall-Mall. London, 1796. Eighteenth-Century Collections Online. Web. 10 Mar. 2015 .

Boydell, Josiah. "List of Paintings Commissioned for the Shakespeare Gallery." Two-page manuscript on paper watermarked 1807. Folger Shakespeare Library. Source call numbers Y.d.369 (1a) and (1b). Hamnet Holdings ID: 120664.

http://luna.folger.edu/luna/servlet/detail/FOLGERCM1 6 6 51626 1038 41:List-of-paintings-commissioned-for?sort=Call_Number\%2CAuthor\%2CCD_Title\%2CImprint\&qvq=q:boydel 1\%2Blist;sort:Call_Number\%2CAuthor\%2CCD_Title\%2CImprint;lc:FOL GERCM1 6 6\&mi $=43 \&$ trs $=46$ 
and

http://luna.folger.edu/luna/servlet/detail/FOLGERCM1 6 6 51658 1038 42:List-of-paintings-commissioned-for-

?sort=Call_Number\%2CAuthor\%2CCD_Title\%2CImprint\&qvq=q:boydel 1\%2Blist;sort:Call_Number\%2CAuthor\%2CCD_Title\%2CImprint;lc:FOL GERCM1 6 6\&mi=44\&trs=46

Burney, Frances. The Diary and Letters of Frances Burney, Madame D'Arblay. Ed. Sarah Chauncey Woolsey, 2 vols. Boston: Little, Brown, 1910. Internet Archive. Web. 10 Mar. 2015.

Dias, Rosie. Exhibiting Englishness: John Boydell's Shakespeare Gallery and the Formation of a National Aesthetic. New Haven: Yale UP, 2013. Print.

Engel, Laura. Fashioning Celebrity: Eighteenth-Century British Actresses and Strategies for Image Making. Columbus, OH: Ohio State UP, 2011. ohiostatepress.org Web. 10 Mar. 2015.

Friedman, Winifred H. Boydell's Shakespeare Gallery. Diss. Harvard U, 1974. New York: Garland, 1976. Print.

Goodden, Angelica. Miss Angel: The Art and World of Angelica Kauffman, Eighteenth-Century Icon. London: Random House, 2011. Google Books. Web. 10 Mar. 2015.

Hawkins, Ann R. "Reconstructing the Boydell Shakspeare Gallery." Shakespeare and the Culture of Romanticism. Ed. Joseph M. Ortiz. Farnham: Ashgate, 2013. 207-29. Print.

Mannings, David. Sir Joshua Reynolds: A Complete Catalogue of his Paintings. 2 vols. New Haven: Yale UP, 2000. Print.

Moore, Evelyn K., and Patricia Anne Simpson, eds. The Enlightened Eye: Goethe and Visual Culture. Amsterdam: Rodopi, 2007. ebrary. Web. 10 Mar. 2015 .

Murray, Christopher John, ed. "Kauffmann, Angelika (1741-1807)." Encyclopedia of the Romantic Era, 1760-1850. London: Routledge, 2013. Google Books. Web. 10 Mar. 2015. 
Repton, Humphry. The Bee; Or, A Companion to the Shakespeare Gallery. London, 1789. Eighteenth-Century Collections Online. Web. 10 Mar. 2015.

Vickers, Brian, ed. William Shakespeare Volume 6: 1774-1801. Part of The Critical Heritage series. General editor B. C. Southam. London: Routledge, 2003. Literary Reference Center Plus. Web. 10 Mar. 2015. 